\title{
Hospital-hotel Service and Quality of Nursing Care According to the Perspective of Inpatients
}

Nalma Alexandra Rocha de Carvalho1, Elaine Cristina Carvalho Moura², Lidya Tolstenko Nogueira², Lariza Martins Falcão ${ }^{3}$, Vanessa Caminha Aguiar Lopes ${ }^{4}$, José Diego Marques Santos ${ }^{5}$, Fernanda Ferreira de Morais ${ }^{6}$

\section{Abstract}

Background: Hospital-hotel services concepts rescue notions of hospitality in hospitalization environment, and include aspects of patient safety. The perspective is to facilitate the act of meeting the needs of both clients and employees of the institution in all dimensions.

Objective: This article aimed to evaluate the perceptions of inpatients about hospital-hotel services in a university hospital with the perspective of quality of care in health assistance.

Method: Descriptive study in a public university hospital conducted from December 2015 to January 2016. A total of 92 patients responded a questionnaire of items based on hospital accreditation parameters on four hospital-hotel services (domains).

Results: It revealed positive parameters of evaluation with average of $91.8 \%$ ( $p<0.001)$ for all domains. There was a negative or neutral appreciation of $40.2 \%$ for comfort in bed, and $88.1 \%$ for information on emergency exits. The results suggest relevant data for quality analysis services offered by hospital-hotel services interfaced with the assistance.

Conclusion: The smooth running of services is essential to comprehensive care in a hospital setting. Leaders and teams committed to the quality of the structure favor processes and results, ensuring quality and patient safety.
1 Nurse. Expertise candidate in Obstetrics for Nursing from Federal University of Piauí.

2 Nurse. PhD Professor in Nursing, PostGraduate Program in Nursing, Federal University of Piauí.

3 Nurse. Master in Clinical Health Care. Nursing teacher at Federal University of Piauí.

4 Nurse. Master's Degree student in Nursing at Federal University of Piauí.

5 Student in Nursing Bachelor Course of Federal University of Piauí.

6 Student in Nursing Bachelor Course of Associação de Ensino Superior do Piauí.

Contact information:

José Diego Marques Santos.

Address: Universidade Federal do Piauí. Campus Universitário Ministro Petrônio Portela. Bairro: Ininga. Teresina, PI, Brazil. ZIP code: 64049-550.

झ jd_ms@live.com 


\section{Introduction}

Users of health services have been, over the years, increasingly demanding regarding structure and service. Health institutions are involved in the adaptation of management systems, infrastructure, logic and human resources, aiming to offer hospitality and humanization in the provision of services in order to minimize the pain for users and reduce hospital stays. To do so, they face challenges [1].

In this context, hospital-hotel services concepts rescue notions of hospitality in hospitalization environment, including aspects of patient safety. These characteristics favour the provision of services that add value and customer loyalty. Classic hospitality concepts adapted to the hospital sector can bring benefit to the client and health teams, providing the humanization and hospitality of the common environment [2]. In this sense, health institutions have sought to create a cozy space for the user, allowing them to express doubts and concerns regarding the service received [3].

Thus, the term that translates the concept of hospital-hotel service is transformation with a focus on hospital infrastructure, people and processes. To this end, efforts are needed to improve hospital architecture, to expand the concept of disease, to include holistic care of emotional, social, environmental needs and humanization and, finally, to deconstruct the current model regarding the bureaucratic dysfunction that cause hospital systems to be "inflexible" [4].

The perspective is to facilitate the act of meeting the needs of both clients and employees of the institution in all dimensions [4]. Furthermore, the understanding of concepts of hospital-hotel services and humanization must appear as key aspect in the center of the hospital's strategic planning, highlighting the customer satisfaction, with the easing of pain and suffering from the trauma of hospitalization [5].

Hospital-hotel services, although belonging to a hospital area, are directly linked to the client and their satisfaction [6]. Thus, there is an intrinsic relationship between the hospital-hotel service and comprehensive care to the client, especially in nursing care. The promotion of measures to comfort and well-being is inherent to the profession of nursing. In addition, it relates directly with the humanized care practices, which are relevant in the restoration of an individual's health since it is through measures of comfort that nurses and their team promote strengthening, hope, consolation, support, encouragement and quality care [7]. Taking this in consideration, it is necessary to conduct studies that approach hospital-hotel services as a factor that influences the quality of nursing care.

In this perspective, this article aimed to evaluate the perceptions of inpatients about hospital-hotel services in a university hospital with the prospect of quality of care in health assistance.

\section{Methods}

This is an exploratory descriptive study, with quantitative approach developed in a University Hospital located at Northeast Brazil. The population of this study was composed of all hospitalized patients in the three operational stations: 1(one) surgical clinic and 2 (two) medical clinics. Inclusion criteria were: state of consciousness preserved, length of stay of at least 24 hours, age over 18 years, hospitalization in hospital wards; and as exclusion criteria: hospitalization in the intensive care unit and outpatient treatment situation. The sample was gathered by convenience, resulting in a total of 92 patients who met the criteria mentioned.

Data production occurred between December 2015 and January 2016. It was used a questionnaire divided in two parts: the first with demographic and clinical data; and the second related to the structure, process and results of the services provided in the hospital. The items of the questionnaire were developed according to the Accreditation 
Manual from the National Accreditation Organization [8] and to the National Policy of Brazilian Humanization [9].

The domains of the questionnaire consisted in factors that compose the hospital-hotel sector: admission services; infirmary; clothing; and food. Each domain included statements that were answered as follows: (1) "I disagree," (2) "I do not agree nor disagree," or (3) "I agree." In addition, it included the evaluation of satisfaction regarding the 4 (four) services in general, which were answered as follows: (1) "Dissatisfied," (2) "Not satisfied nor dissatisfied," (3) "Very pleased."

The data were analyzed in the Statistical Packa-

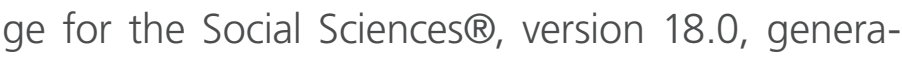
ting descriptive statistics, such as average, median, standard deviation, interquartile range, minimum and maximum range for the quantitative variables. Frequencies were calculated for variables with categorical measurement levels. The evaluative items were analysed and the T-test was conducted in one sample in order to check for differences between the statements of the sample group.

The development of study met national and international standards of ethics in research involving humans. The Research Ethics Committee of the Federal University of Piauí, under Process n ${ }^{\circ}$ 1.322.975, approved it. The participants signed two copies of informed consent.

\section{Results}

The 92 (100\%) participants of this study had an average age of 47.7 ( \pm 16.1 ) years, with a minimum and maximum age of 83.3 and 19.1 years, respectively. Most of them, 53 participants (57.6\%), were female, and 39 (42.4\%) were male; 48 (52.2\%) were married or in stable relationship, followed by 35 (38.0\%) singles and 9 (9.83\%) divorced or separated. Regarding education, 31 (33.7\%) had only incomplete elementary school and 16 (17.4\%) were not literate. From those who reported having higher levels of education, 19 reported complete elementary school (20.7\%), 21 complete high school (22.8\%) and only five (5.4\%) higher education.

When asked about the profession, 24 (26.1\%) were retired, 21 (26.1\%) unemployed, 16 (17.4\%) farm workers, and 9 (9.8\%) self-employed. In addition, $20(21.7 \%)$ participants mentioned nine occupations that did not require higher education. These participants had also mentioned two professions that require higher education: there were two teachers (2.2\%) and one journalist (1.1\%). At the time of the interview, 73 (79.3\%) mentioned having family income between one and three minimum wages, and 16 (17.4\%) had income less than one minimum wage.

As for clinical data, in a range of two years, 51 (55.4\%) patients reported the current hospitalization as their first one. The others, 13 (14.1\%), reported having been admitted 3 or 4 times, and 11 (12.0\%) reported having been hospitalized 5 to 6 times during this period of two years. The current period of hospitalization had a 7.5 ( \pm 16.1) days average, with a minimum of one day and a maximum of 76 days. Regarding medical diagnosis, 34 (37.0\%) reported diseases of the gastrointestinal tract and annexes, followed by 11 (12\%) neoplasia, $8(8.7 \%)$ diseases of the epithelial/connective tissue and 7 (7.6\%) anemias. Considering the diet during the period of hospitalization, 37 participants (40.2\%) reported receiving soft diet, 25 (27.2\%) regular diet, 14 (15.2\%) low-sodium diet, and 12 (13.0\%) liquid diet.

The Tables 1 to 4 contain the results of the hospital-hotel sector evaluation, and the Table 5 contains the results of the satisfaction evaluation, considering the services of reception of the inpatient sector, infirmary cleaning, clothing, trousseau and food at the university hospital.

The entirety of items included in the evaluation of reception service during the hospital admission showed a statistically significant difference $(p<$ 
Table 1. Patient's evaluation about the admission service at the university hospital. Teresina, PI, Brazil, 2016.

\begin{tabular}{|c|c|c|c|c|}
\hline \multirow[b]{2}{*}{ Variable } & \multicolumn{3}{|c|}{ n (\%) } & \multirow{2}{*}{$\begin{array}{l}\mathrm{p} \\
\text { valor* }\end{array}$} \\
\hline & \begin{tabular}{c|} 
I \\
disagree
\end{tabular} & $\begin{array}{l}\text { I do not agree } \\
\text { nor disagree }\end{array}$ & I agree & \\
\hline $\begin{array}{l}\text { The care I received at reception/ } \\
\text { hospitalization was agile and } \\
\text { quick. }\end{array}$ & $2(2.2)$ & $4(4.3)$ & $86(93.5)$ & $<0.001$ \\
\hline $\begin{array}{l}\text { The place destined to wait in the } \\
\text { lobby was comfortable. }\end{array}$ & & $2(2.2)$ & $90(97.8)$ & $<0.001$ \\
\hline $\begin{array}{l}\text { The hostesses treated me with } \\
\text { warmth and attention. }\end{array}$ & & & $92(100)$ & $<0.001$ \\
\hline $\begin{array}{l}\text { The reception was a pleasant } \\
\text { environment. }\end{array}$ & & $2(2.2)$ & $90(97.8)$ & $<0.001$ \\
\hline $\begin{array}{l}\text { I was informed about the use of } \\
\text { the locker. }\end{array}$ & $12(13)$ & $7(7.6)$ & $73(79.3)$ & $<0.001$ \\
\hline $\begin{array}{l}\text { I was approached by health } \\
\text { professionals on hospitalization in } \\
\text { accordance with my needs. }\end{array}$ & $2(2.2)$ & & $90(97.8)$ & $<0.001$ \\
\hline $\begin{array}{l}\text { There were signs with easy } \\
\text { viewing and understanding in the } \\
\text { admission/reception. }\end{array}$ & $2(2.2)$ & $9(9.8)$ & $81(88.0)$ & $<0.001$ \\
\hline $\begin{array}{l}\text { I was provided with information } \\
\text { necessary for my hospitalization, } \\
\text { including the hospital's norms. }\end{array}$ & $5(5.4)$ & $4(4.3)$ & $83(90.2)$ & $<0.001$ \\
\hline I feel safe in this hospital. & $1(1.1)$ & $2(2.2)$ & $89(96.7)$ & $<0.001$ \\
\hline $\begin{array}{l}\text { I was instructed on emergency } \\
\text { exits. }\end{array}$ & $79(85.9)$ & $2(2.2)$ & $11(12.0)$ & $<0.001$ \\
\hline $\begin{array}{l}\text { The reception/hospitalization staff } \\
\text { identified themselves. }\end{array}$ & $6(6.5)$ & $3(3.3)$ & $83(90.2)$ & $<0.001$ \\
\hline $\begin{array}{l}\text { The reception/hospitalization staff } \\
\text { was identified. }\end{array}$ & $3(3.3)$ & $5(5.4)$ & $84(91.3)$ & $<0.001$ \\
\hline \multicolumn{4}{|l|}{ Total } & $92(100)$ \\
\hline & Coumas: & ct rescorch $x$ & T Toct of & e sample \\
\hline
\end{tabular}

Table 2. Patient's evaluation about the infirmary and cleanliness of the university hospital. Teresina, PI, Brazil, 2016.

\begin{tabular}{|c|c|c|c|c|}
\hline \multirow[b]{2}{*}{ Variable } & \multicolumn{3}{|c|}{ n (\%) } & \multirow{2}{*}{$\begin{array}{l}\mathrm{p} \\
\text { valor* }\end{array}$} \\
\hline & $\begin{array}{l}\text { I do not } \\
\text { agree }\end{array}$ & $\begin{array}{l}\text { I do not agree } \\
\text { nor disagree }\end{array}$ & I agree & \\
\hline The hospital bed is comfortable. & $27(29.3)$ & 10(10.9) & $55(59.8)$ & $<0.001$ \\
\hline $\begin{array}{l}\text { I felt that my privacy was preserved in the } \\
\text { infirmary. }\end{array}$ & $7(7.6)$ & $11(12.0)$ & $74(80.4)$ & $<0.001$ \\
\hline $\begin{array}{l}\text { I felt that my privacy was preserved during the } \\
\text { visits of health professionals. }\end{array}$ & $4(4.3)$ & $7(7.6)$ & $81(88.0)$ & $<0.001$ \\
\hline $\begin{array}{l}\text { The infirmary's decor and ambience promoted } \\
\text { your well-being. }\end{array}$ & & $5(5.4)$ & $87(94.6)$ & $<0.001$ \\
\hline $\begin{array}{l}\text { My inpatient ward is satisfactorily clean and } \\
\text { organized. }\end{array}$ & & $4(4.3)$ & $88(95.7)$ & $<0.001$ \\
\hline My inpatient ward is well lit and ventilated. & & $2(2.2)$ & $90(97.8)$ & $<0.001$ \\
\hline My inpatient ward is noisy during the day. & $82(89.1)$ & $3(3.3)$ & $7(7.6)$ & $<0.001$ \\
\hline My inpatient ward is noisy during the night. & $79(85.9)$ & $3(3.3)$ & $10(10.9)$ & $<0.001$ \\
\hline $\begin{array}{l}\text { Stretchers and wheelchairs have easy in and out } \\
\text { routes on my inpatient ward. }\end{array}$ & & $1(1.1)$ & $91(98.9)$ & $<0.001$ \\
\hline $\begin{array}{l}\text { My inpatient ward has satisfactory number of } \\
\text { beds. }\end{array}$ & $1(1.1)$ & $1(1.1)$ & $90(97.8)$ & $<0.001$ \\
\hline $\begin{array}{l}\text { My inpatient ward has provided local comfort for } \\
\text { my caregivers/relatives to rest. }\end{array}$ & $8(8.7)$ & $3(3.3)$ & $81(88)$ & $<0.001$ \\
\hline $\begin{array}{l}\text { The trash bins of my infirmary are emptied before } \\
\text { they overflow. }\end{array}$ & & & $92(100)$ & $<0.001$ \\
\hline $\begin{array}{l}\text { The bathrooms of my infirmary are cleaned } \\
\text { frequently and are free of bad smell. }\end{array}$ & & $4(4.3)$ & $88(95.7)$ & $<0.001$ \\
\hline $\begin{array}{l}\text { In cases of vomiting, urine and/or other situations, } \\
\text { the infirmary's cleaning staff is quick and agile. }\end{array}$ & $1(1.1)$ & $1(1.1)$ & $90(97.8)$ & $<0.001$ \\
\hline $\begin{array}{l}\text { The staff carry me safely and cordially in the } \\
\text { stretcher. }\end{array}$ & $1(1.1)$ & $2(2.2)$ & $89(96.7)$ & $<0.001$ \\
\hline Total & & & & $92(100)$ \\
\hline
\end{tabular}

This article is available at: www.intarchmed.com and www.medbrary.com 
Table 3. Evaluation of patients about the clothing/bed linen at the university hospital. Teresina, PI, Brazil, 2016.

\begin{tabular}{|c|c|c|c|c|}
\hline \multirow[b]{2}{*}{ Variable } & \multicolumn{3}{|c|}{ n (\%) } & \multirow{2}{*}{$\stackrel{p}{p}$} \\
\hline & $\begin{array}{l}\text { I do not } \\
\text { agree }\end{array}$ & $\begin{array}{l}\text { I do not agree } \\
\text { nor disagree }\end{array}$ & I agree & \\
\hline I consider the bed sheets comfortable. & $1(1.1)$ & $1(1.1)$ & $90(97.8)$ & $<0.001$ \\
\hline I feel comfort and well in my bed. & $2(2.2)$ & $2(2.2)$ & $88(95.7)$ & $<0.001$ \\
\hline $\begin{array}{l}\text { I feel comfort and well with the aroma of my } \\
\text { sheets after daily changing. }\end{array}$ & 1(1.1) & $1(1.1)$ & $90(97.8)$ & $<0.001$ \\
\hline $\begin{array}{l}\text { The bed clothing change is enough considering } \\
\text { my health status. }\end{array}$ & $1(1.1)$ & $2(2.2)$ & $89(96.7)$ & $<0.001$ \\
\hline $\begin{array}{l}\text { Bed clothing change is performed without } \\
\text { causing me discomfort. }\end{array}$ & $1(1.1)$ & $2(2.2)$ & $89(96.7)$ & $<0.001$ \\
\hline $\begin{array}{l}\text { My bed sheets, blankets and pillowcases are in } \\
\text { good condition. }\end{array}$ & $2(2.2)$ & $4(4.3)$ & $86(93.5)$ & $<0.001$ \\
\hline My bed sheets are changed at least once a day. & & & $92(100)$ & $<0.001$ \\
\hline My hospital gowns are comfortable. & $8(8.7)$ & $2(2.2)$ & $82(89.1)$ & $<0.001$ \\
\hline $\begin{array}{l}\text { The hospital gowns provided are according to } \\
\text { my health needs. }\end{array}$ & & $1(1.1)$ & $91(98.9)$ & $<0.001$ \\
\hline Total & & & & $92(100)$ \\
\hline
\end{tabular}

Source: direct research. * T Test of one sample

Table 5. Evaluation of patients regarding hospitalization satisfaction at the university hospital. Teresina, PI, Brazil, 2016.

\begin{tabular}{|c|c|c|c|c|}
\hline \multirow{2}{*}{ Variable } & \multicolumn{3}{|c|}{ n (\%) } & \multirow{2}{*}{$\begin{array}{c}p \\
\text { valor* }\end{array}$} \\
\hline & Dissatisfied & NSND & Very pleased & \\
\hline Hospital's admission service & $1(1.1)$ & $2(2.2)$ & 89(96.7) & $<0.001$ \\
\hline Infirmary cleanliness & $1(1.1)$ & $5(5.4)$ & $86(93.5)$ & $<0.001$ \\
\hline Hospital's clothing/Bed linen & & $5(5.4)$ & $87(94.6)$ & $<0.001$ \\
\hline Food service & $4(4.3)$ & $4(4.3)$ & $84(92.3)$ & $<0.001$ \\
\hline Total & & & & $92(100)$ \\
\hline
\end{tabular}

Source: direct research. * T Test of one sample
Table 4. Evaluation of patients regarding the food service during hospitalization at the university hospital. Teresina, PI, Brazil, 2016.

\begin{tabular}{|c|c|c|c|c|}
\hline \multirow[b]{2}{*}{ Variable } & \multicolumn{3}{|c|}{ n (\%) } & \multirow[b]{2}{*}{$\begin{array}{l}\mathrm{p} \\
\text { valor* }\end{array}$} \\
\hline & $\begin{array}{l}\text { do not } \\
\text { agree }\end{array}$ & $\begin{array}{l}\text { I do not agree } \\
\text { nor disagree }\end{array}$ & I agree & \\
\hline $\begin{array}{l}\text { In my menu there is food diversity in } \\
\text { accordance with my health status. }\end{array}$ & $5(5.4)$ & $7(7.6)$ & $80(87.0)$ & $<0.001$ \\
\hline $\begin{array}{l}\text { Meals offered at this hospital have } \\
\text { satisfactory appearance, flavour and } \\
\text { aroma. }\end{array}$ & 10(10.9) & $9(9.8)$ & $73(79.3)$ & $<0.001$ \\
\hline $\begin{array}{l}\text { The amount of food offered in this } \\
\text { hospital is enough for my nutritional } \\
\text { needs. }\end{array}$ & $2(2.2)$ & $3(3.3)$ & $87(94.6)$ & $<0.001$ \\
\hline $\begin{array}{l}\text { The meal schedule in this hospital } \\
\text { meets my needs. }\end{array}$ & & $2(2.2)$ & $90(97.8)$ & $<0.001$ \\
\hline $\begin{array}{l}\text { The temperature of the food offered } \\
\text { in this hospital is suitable to preserve } \\
\text { the taste of food. }\end{array}$ & $3(3.3)$ & $5(5.4)$ & $85(92.4)$ & $<0.001$ \\
\hline $\begin{array}{l}\text { My doubts about my meals have been } \\
\text { answered with courtesy. }\end{array}$ & $1(1.1)$ & $3(3.3)$ & $88(95.7)$ & $<0.001$ \\
\hline $\begin{array}{l}\text { The professionals who are responsible } \\
\text { for my meals are attentive to my } \\
\text { needs and health status. }\end{array}$ & $1(1.1)$ & $4(4.3)$ & $87(94.6)$ & $<0.001$ \\
\hline $\begin{array}{l}\text { The professionals who are responsible } \\
\text { for my meals are gentle and attentive. }\end{array}$ & & $2(2.2)$ & $90(97.8)$ & $<0.001$ \\
\hline $\begin{array}{l}\text { The kitchen maids and other members } \\
\text { of the kitchen staff are cordial during } \\
\text { their assistance. }\end{array}$ & & $1(1.1)$ & 91(98.9) & $<0.001$ \\
\hline $\begin{array}{l}\text { Meals in the hospital are served with } \\
\text { punctuality. }\end{array}$ & & $1(1.1)$ & 91(98.9) & $<0.001$ \\
\hline $\begin{array}{l}\text { I was introduced to the nutritionists } \\
\text { responsible for my diet. }\end{array}$ & $6(6.5)$ & $1(1.1)$ & $85(92.4)$ & $<0.001$ \\
\hline Total & & & & $92(100)$ \\
\hline
\end{tabular}


0.001) among the trials carried out. In addition, there was a positive agreement with activities executed during the service provided by the hospital, considering that 73 participants (79.3\%) agreed positively with item 5 (five) and 92 (100\%) with item 3 (three). These items dealt, respectively, with the availability and clarification about the locker, and the reception with warmth and attention. The exception was item 10, which dealt with the statement about the emergency exits, considering that this item presented negative review from 79 participants (85.9\%), as shown in Table 1.

Patients evaluated the infirmary and the cleanliness of the ward in which they were hospitalized and, as the sector evaluated previously, all 92 items (100\%) showed a statistically significant difference $(p<0.001)$ between the trials conducted. A positive assessment prevailed considering the services provided during the hospitalization. At least 55 (59.8\%) agreed positively with item 1 (one) and a maximum of 92 (100\%) agreed positively with item 12 , which, respectively, state that the hospital bed is comfortable and the bins of the inpatient ward are emptied before overflow. The items 7 (seven) and 8 (eight) contain negative statements. Most of the respondents disagreed with these assertions, showing a positive assessment regarding the noise in the infirmary during the day (89.1\%) and during the night (85.9\%), as described in Table 2 . The greater dissatisfaction was shown regarding the comfort on hospital bed, since 27 participants (29.3\%) disagreed with item 1 (one).

The last evaluated service was the food service. As the previous items, it showed a statistically significant difference $(p<0.001)$ on the trials. The answer "I agree" was chosen predominantly in all the statements. The item 2 (two), which states that "meals offered at this hospital have satisfactory appearance, flavour and aroma," is the item with less agreement answers: 73 (79.3\%) positive responses. On the other hand, greater approval was seen in items 9 (nine) and 10, with 91 (98.9\%) positive responses each. These items stated that the kitchen staff and other members of the kitchen staff are cordial during their assistance, and meals in the hospital are served with punctuality (Table 4).

\section{Discussion}

The perceptions of the users admitted to the hospital about hospital-hotel services were promising and offered elements that may interact with the quality of nursing care. In general, the results presented a satisfactory assessment of the hospitalhotel services, considering that the average of positive results in all the domains were 91.8\% ( $p<$ $0.001)$. This positive assessment is related to the fulfillment of safety levels according to hospital accreditation, which suggests the quality level for the services provided from hospital admission to the food service.

There has been a movement towards quality in hospitals, which results in the need for fundamental changes in organizations that pursues individuals' valorization and attention to social relations that became indispensable for the acquisition of the title of excellence. Through the quality policy established by the institutions, professionals engage in and strengthen the client-centered improvement culture focused in running services that meet the requirements of the National Accreditation Organization, safely and with excellence [10].

This reality was observed in this study and was expressed even by people who have health care services provided exclusively by the public and free Brazilian Health System (SUS), which is the main profile of the sample investigated. It is noted that participants with low socioeconomic conditions are still attentive to safety and quality parameters.

Overall, the results in the field of hospitalization admission were positive. What may have collaborated to this result is the fact that the hospital studied is practicing a pilot project of rules for users and 
visitors during their stay in hospital. Therefore, task forces and monitoring activities were applied by the hospital-hotel and by the professionals responsible for informing these standards.

A similar result was found in a descriptive exploratory study conducted with 51 patients in order to assess the quality of the structure and the fulfillment process of some services of a university hospital from the perspective of the users. The assessment included the admission service process, considering aspects such as the care rapidity, attention provided by the health professionals, and waiting rooms. The study found satisfaction by more than $90 \%$ of the participants. However, when it comes to information about admission rules, it was found that the communication between professionals and patients needed some improvements [11].

Despite an overall average of satisfactory results in the hospitalization admission domain, the item that dealt with receiving information about emergency exits (item 10) presented a negative result. It is possible to notice that there is a lack of awareness among patients about the location of emergency exits, even though in item 7 (seven) patients mostly reported that there are signs with easy viewing and understanding in the admission/reception.

One can understand that the presence of signs with easy visualization does not necessarily results in the understanding or perception of the verbal and/ or non-verbal language contained in these signs. For example, the ignorance of the location of the emergency exits did not seem to be a safety concern for the participants, which is an important aspect because this unawareness may result in misfortunes that impact decisively on patient safety.

Three years ago, in the city of Santa Maria, Rio Grande do Sul, Brazil, a tragedy occurred in a nightclub, with more than 240 deaths. Among the causes for the large number of deaths, the inadequate features of space regarding signals, size and location of emergency exits that hampered the evacuation were cited [12]. As usually noticed in this kind of tragedy, there are many factors related to the occurrence of the accident. It is possible to say that this tragedy is a terrible example of how there is still much too do in the area of planning environments [13].

The cleaning and sanitizing domain was analyzed according to the infirmary's interface. This is the domain that has the greater amount of claims. All items have been assessed positively. The data about the hygiene of toilets and of the infirmary and emptying of trash bins was more satisfactory. These results are encouraging given that the hygiene and cleanliness of the entire hospital environment are of great importance for promoting patient safety by reducing the risk of infections related to health services [14].

The item 1 (one) of this category, which assesses the comfort of the hospital bed, obtained fewer positive responses. On the other hand, the domain with greater approval was the one regarding hospital's clothing/bed linen and items as comfort, cleanliness, and amount of bed blankets and hospital gowns. It is worth mentioning that comfort is directly connected to patients' health status and their recovery. Comfort becomes critical when related to the nursing practice. It is a goal to be achieved by assistance, therefore it is considered as a desired outcome for patient care in order to meet individuals' expectations and needs and, consequently, achieve a more natural and humanized assistance [7].

Comfort in the hospital bed is also related to the period of hospitalization because health care quality can be impaired throughout extensive periods of time. Prolonged hospitalization is more likely to be associated with hospital infection, malnutrition, pressure ulcer development and various other factors that damage patients' health status [15].

This study showed an average of 7.5 days of hospitalization. In a descriptive study conducted in a university hospital's hospitalization sector, 244 pa- 
tients showed an average length of stay of 16.77 days. It is noteworthy that the Brazilian national average of days of hospitalization is 9.3 days in medium and high complexity hospitals [16].

In the present study, the clients did not consider that the levels of daytime and nighttime noise caused discomfort. This data was expressed, respectively, by $89.1 \%$ and $85.9 \%$ of participants.

Considering the silence in the ward during daytime and nighttime, data from this study does not relate to the findings of a study conducted in a university hospital in São Paulo, 2013, which concluded that the minimum and maximum noise levels in all sectors, except for the neonatal intensive care unit, exceeded those provided by specific legislation for hospitals. The noise levels' variation is a characteristic of environments with intermittent noise that pose a risk to hearing health [17]. It is noteworthy that this study did not compare parameters with specific legislation when making this assessment.

Regarding the food domain, which was the last Hospital-hotel service analyzed, all items reached a high percentage of agreements. The item 2 (two), which referred to appearance, flavor and aroma of meals provided, had the lower acceptance of this domain (79.3\%). The item that states that patients' needs are met regarding doubts concerning their meals (Item 6), and the one referring to being presented to nutritionists responsible for their diet had a higher number of correlation $(95.7 \%$ and 92.4\% respectively). It is possible to observe that despite the lower patient satisfaction regarding the appearance, taste and aroma of meals provided, they had access to the nutritionists responsible for making adjustments that meet their specific clinical features.

In this context, there must be an effective communication system between the nutritionists and the clients, so that the patient can understand their health treatment and support their dietary restrictions. Diet addition and/or exchange are not always allowed because of the patient's condition and specificity of treatment and, in such situations, each case must be assessed individually [11].

The most frequent pathologies were the gastrointestinal tract and attachments diseases (37.0\%), neoplasia (12\%), epithelium/connective tissue diseases (8.7\%) and anemias (7.6\%). Pathologies presented by the patients are directly linked to the diet prescribed to them; for example, gastrointestinal disorders require lighter diets. Regarding the present study, prevailing diets were soft diet (40.2\%), regular diet (27.2\%), low-sodium diet (15.2\%), liquid $\operatorname{diet}(13.0 \%)$.

A cross-sectional study conducted in an oncology unit of a tertiary hospital interviewed 100 cancer patients and aimed to evaluate the acceptance of hospital diets. The study found that the reported reasons for non-acceptance of the offered diet were the following: lack of taste (40\%), monotony of preparations (33\%), excessive amount (29\%), lack of appetite (26\%), and inadequate temperature of meal (24\%) [18].

Among sensory and environmental aspects, it was found that the temperature of the food had great acceptance $(92.4 \%)$, despite the fact that the distribution carts as well as the utensils that contain the meals are not heated. The number of beds and the long distance covered per kitchen maids are other factors that can contribute to the inadequate result of food service. The temperature is a factor that influences the acceptance of meals [19].

The customization and improvement of appearance, aroma, texture and taste are important strategies to alleviate the lack of flavor of these diets. Considering the several factors that influence food acceptance, it is crucial to be concerned with and to control all stages of food production, from planning to preparation and distribution [20].

Therefore, for better customer service, nurses should understand the meaning of the diet to patients. The patients' interpretations about their diet, body, and world are paramount in dietary 
care and, also, in practices of health education developed by nurses, whether in the community or in the hospital. It is important to understand the food culture and its social aspects in order to build forms of intervention in the diet of an individual or group [21].

In general, there was a great satisfaction in the four analysed services, showing a good evaluation of the services of hospitalization reception, nursing, cleaning, clothing/bed linen, and food. This study focused on the main hospital-hotel services, being different from studies available in the literature that focus in decentralized services in hospital structure. It may be easier to find results that are more satisfactory regarding structure in the hospital environment in hospitals that have a hospital-hotel sector that incorporates all the services discussed in this study.

These aspects enable the creation of a bond between clients and the service, which may spread positive images to new clients through information about the care provided by the service. In addition, the client gains confidence in the institution when they know and experience satisfactory services [22].

It is known that a health organization must meet the technical and functional necessities involved in the holistic health care in order to meet the quality requirements. To do so, it is necessary to consider the individual needs and promote a suitable environment for care [11].

Quality or health care management programs are recommended since they seek to overcome the deficiencies in infrastructure management, materials and equipment, and create improvements measures that support excellence and the humanization of population health care. Even though there are health services that use quality devices, most of these services present lack of monitoring and quality control systems [23].

Considering the assessment of health quality, the Donabedian Model, which comprehends the analysis of the tripod structure-process-outcome, is one of the methods widely used by researchers and government agencies. In this model, the term "structure" corresponds to the quite stable characteristics of the institutions such as physical area, human, material and financial resources and the organizational model. The term "process" refers to the set of activities generally developed in production. Inside the health sector, it is related to the relationships established between professionals and patients, from the act of seeking for health care assistance to the establishment of diagnosis and treatment. The term "outcome" comprehends the characteristics of goods or services whose quality is reflected on the effects on the health of customer and population [24].

Although the four (4) areas (hospital reception, cleaning, clothing/bed linen and food) are mainly related to structure and process, they also influence the outcome directly because these dimensions are facilitating the development of service quality and good results in order to reach the excellence standard of quality, especially for nursing. Overall, there was a very high satisfaction rate (over 92\%), which emphasizes the quality of services offered by the hospital-hotel sector.

Taking the results of this study in consideration, it is possible to argue that the hospital-hotel service is a promising area for nurses since they have training on hospital management and patient needs, adding concepts of leadership in executing processes that are essential for quality management in the sector. Their responsibilities cover activities such as hiring, supervision and guidance of employees, as well as health promotion activities guided by the concepts of comfort and well-being.

\section{Conclusion}

In assessing the perceptions of inpatients about hospital-hotel services with a focus on the quality of patient care, it is clear that the smooth running of services is essential to comprehensive care in a hos- 
pital. Leaders and teams committed to the quality of the structure are able to develop processes and results that ensure quality and safety of hospitalized patients.

In this sense, this study presents specific contributions to the administration and management of hospital resources, and draws attention to the multidimensional understanding of the hospital-hotel. The repercussions of hospital-hotel institutions must surpass the physical dimension of hospital in order to achieve the holistic nursing care, especially when it comes to promoting patient comfort and safety, becoming once more a management opportunity for nurses.

Therefore, it is necessary a larger approach to the subject hospital-hotel service in future epistemological productions, aiming to cease the novelty still present in this topic and to establish measures that result in high levels of satisfaction in the act of welcoming the patients in hospital-hotel services. Although this study is relevant, it is important to acknowledge the existence of limitations since there is no relationship between the study variables.

\section{References}

1. Ribeiro ABA. Hotelaria hospitalar como um diferencial no setor de saúde. Revista Especialize On-line IPOG. 2013; 1(6): 1-14.

2. Barbosa JG, Meira PL, Dyniewicz AM. Hotelaria hospitalar novo conceito em hospedagem ao cliente. Cogitare Enferm. 2013; 18(3):587-91.

3. Souza RCR. Soares ES, Cordeiro CEM, Silva ML. Ombudsman service in hospital administration: a friendly environment for healthcare system users. Cuid fundam Online. 2010; 2(3): 106270 .

4. Oliveira C, Gomes EF, Racanel FCl, Velasquez GG, Lopes MR. A hotelaria hospitalar como uma nova perspectiva de atuação em organizações de saúde. Turismo: Estudos e Práticas - UERN. 2012; 1(2): 191-209.

5. Pinochet LHC, Galvão CFG. Aspectos humanos na gestão hospitalar. O Mundo da Saúde. 2010; 34(4): 498-507.

6. Tomazzoni EL, Santos AF. Formação e atuação profissionall em hotelaria hospitalar na cidade de São Paulo. Revista Hospitalidade. 2014; 11(1): 107-30.
7. Pott FS, Stahlhoefer T, Felix JVC, Meier MJ. Medidas de conforto e comunicação nas ações de cuidado de enfermagem ao paciente crítico. Rev Bras Enferm. 2013; 66(2): 174-9.

8. ONA: Organização Nacional de Acreditação [Internet]. Ona.org. br. 2016 [cited 3 November 2016]. Available from: http://www. ona.org.br/Inicial

9. Ministério da Saúde (BR). Humaniza SUS: Política Nacional de Humanização: a humanização como eixo norteador das práticas de atenção e gestão em todas as instâncias do SUS. Brasília: Ministério da Saúde, 2004.

10. Manzo BF, Brito MJM, Corrêa AR. Implicações do processo de Acreditação Hospitalar no cotidiano de profissionais de saúde. Rev Esc Enferm USP. 2012; 46(2): 388-94.

11. Seleghim MR, Teixeira JA, Matsuda LM, Inoue KC. Avaliação de usuários sobre a qualidade dos serviços de um pronto socorro. Rev RENE. 2010; 11(3): 305-15.

12. Silva Filho, LCP. (Coord.). Análise do Sinistro na Boate Kiss, em Santa Maria, RS. Porto Alegre: CREA-RS [Internet]. 2013 [acesso em 16 jan 2016]. Disponível: http://www.crea-rs.org. br/site/documentos/documentos10/relatorio\%20comissao\%20 especial\%20final.pdf

13. Braga HC, Moita GF, Camargo F, Almeida PEM. Simulação da movimentação de pessoas em situações de emergência: aspectos ergonômicos e computacionais com autômatos Fuzzy e sua aplicação ao projeto arquitetônico. Ambient constr. 2014; 14(2): 61-77.

14. Ferreira AM, Andrade D, Rigotti MA, Ferreira MFF. Condition of cleanliness of surfaces close to patients in an intensive care unit. Rev Latinoam Enferm. 2011; 19(3): 557-64.

15. Tiensoli SD, Bonisson RL, Matozinhos FP, Meléndez GV, Velásquez FSL. Situational diagnosis: sociodemographic and clinical profile of patients admitted to a clinical medicine unit. Rev Min Enferm. 2014; 18(3): 579-84.

16. Moraes A, Barbosa HB, Campos T, Nicola AL. Análise da demanda de assistência de enfermagem aos pacientes internados em uma unidade de Clinica Médica. Fiep bulletin. 2014; 84(especial): 1-6.

17. Silva MC, Luz VB, Gi D. Noise in the hospital setting: impact on quality of life. ACR. 2013; 18(2):109-19.

18. Ferreira D, Guimarães TG, Marcadenti A. Acceptance of hospital diets and nutritional status among inpatients with cancer. Einstein. 2013; 11(1):41-6. 
19. Sousa AA, Gloria MS, Cardoso TS. Aceitação de dietas em ambiente hospitalar. Rev Nutr. 2011; 24(2): 287-94.

20. Filipini K, Gomes CC, Carvalho APPF, Vieira LL. Aceitação da dieta hipossódica com sal de cloreto de potássio (sal light) em pacientes internados em um hospital público. RAS. 2014; 12(41): 11-18.

21. Martins MCA. A alimentação humana e a Enfermagem: em busca de uma dietética compreensiva. Rev Enf Ref. 2011; 3(4):143-9

22. Pena MM, Melleiro MM. Grau de satisfação de usuários de um hospital privado. Acta paul enferm. 2012; 25(2): 197-203.

23. Bonato VL. Gestão de qualidade em saúde: melhorando assistência ao cliente. O Mundo da Saúde. 2011; 35(5): 319-31.

24. Yuri NE, Tronchin DMR. Qualidade assistencial na Divisão de Enfermagem Materno-Infantil de um Hospital Universitário na ótica de enfermeiros. Rev Esc Enferm USP. 2010; 44(2): 331-8.

Publish in International Archives of Medicine

International Archives of Medicine is an open access journal publishing articles encompassing all aspects of medical science and clinical practice. IAM is considered a megajournal with independent sections on all areas of medicine. IAM is a really international journal with authors and board members from all around the world. The journal is widely indexed and classified Q2 in category Medicine. 